\title{
The Effect of Hydrogel on Plant Growth
}

\author{
Regina Ramilevna Yangirova ${ }^{1}$, Gazizov Asgat Mazhatovich ${ }^{1,2}$, Hafizov Ildar Fanilevich ${ }^{1}$ \\ ${ }^{1}$ Department of "Fire and Industrial Safety", Ufa State Petroleum Technical University, Ufa, Russia Federation \\ ${ }^{2}$ Department of "Fire and Industrial Safety", Ural State Forestry University, Yekaterinburg, Russian Federation
}

\section{Email address:}

regina-moda@mail.ru (R. R. Yangirova)

\section{To cite this article:}

Regina Ramilevna Yangirova, Gazizov Asgat Mazhatovich, Hafizov Ildar Fanilevich. The Effect of Hydrogel on Plant Growth. International Journal of Oil, Gas and Coal Engineering. Vol. 9, No. 4, 2021, pp. 59-62. doi: 10.11648/j.ogce.20210904.12

Received: August 16, 2021; Accepted: August 31, 2021; Published: September 27, 2021

\begin{abstract}
One of the problems of growing seedlings at home is that the garden land is infected with pathogenic organisms. A hydrogel is a water-absorbing polymer in the form of granules, which has a unique ability. It can absorb and retain up to 1 liter of water per $10 \mathrm{~g}$ of hydrogel when swollen. The most well-known are polyacrylamide-based hydrogels. When the hydrogel is in a dry state, the polymer chains are in a "folded" state, when water is added, they diverge and water penetrates inside. The granules swell with the formation of a hydrogel. Hydrogels are essentially made on the basis of environmentally friendly polymers. It is non-toxic, retains all its original properties at different (low and high) temperatures in the soil for five years. Therefore, the main goal of my work is to study the effect of hydrogel on plant growth. Tasks of this work: 1) To study the peculiarities of growing plants in hydrogel. 2) Determine the moment of plant life at which it is better to use hydrogel for them 3) Consider the possibility of growing indoor crops in hydrogel.
\end{abstract}

Keywords: Hydrogel, Plants, Growth, Land, Fertilizers

\section{Introduction}

The term hydrogel is understood as polymer compounds. They are initially in a "bent" state, but if you add a little water, they disperse and the water makes its way inside. The granules expand with the formation of a hydrogel. [1] The polymer is able to hold a huge amount of water, as well as water-soluble fertilizers. [2] In the hot season, it helps to moisturize plants well and even replace irrigation, thereby retaining a large volume of water and eliminating irrigation, which significantly increases crop yields. Thus, the use of hydrogel is a very promising and effective method in waterless and dry areas.

Crystals of dry hydrogel powder are similar to sugar crystals, they are of different shapes and sizes. [3] When water is added to the granules, the crystals increase their volume by 300 times, and the resulting jelly-like mass is used for planting plants or preparing the soil. If there is not enough water in the soil, the swollen crystals will give it away, and if the soil is too moist, they will, on the contrary, absorb it. In order for the plant to use hydrogel water, the roots need to germinate into hydrogel granules or come into contact with them [4]. This takes about 1.5-2 weeks. Due to its properties, the introduction of hydrogel improves clay soils, it loosens them. It also has an effective effect on loose soils, compacting them. [5]. The introduction of such hydrogel granules is enough for 5 years [6]. It dries and swells periodically, without breaking down and retaining its properties during freezing and thawing of the soil (freezing-thawing of the gel [12]).

The advantages of the hydrogel are that it is not toxic. Its advantage is also that it is sterile [7]. It is able to completely decompose, so it does not clog the soil. During decomposition, nitrogen, carbon dioxide and water are released. The gel is destroyed by microbes, and the more active they are and there are more of them, the faster this will happen. [13] But the use of hydrogel also has its drawbacks. For example, there are no nutrients in it. When applying fertilizers to the hydrogel, its own salt concentration is necessary. So, it is necessary that it does not exceed $0.2 \%$ ( 2 grams per liter of water) or the gel does not completely swell [8].

Aquagrunt (ecogrunt or hydrogrunt) is a polymer in structure that is very similar to a hydrogel. But it is very different in physical properties with it (much denser than hydrogel, which makes it more difficult for the plant to take water from it and germinate through it) [9]. The swelling time of the aquagrunt granules in the water reaches up to 10 
hours, and the hydrogel in turn reaches up to 1.5 hours, and much less water is absorbed. The granules of the aquagrunt increase in size up to 10-15 times from the original [10].

Aquagrunt is often used for decorative purposes. [11]. It is decorated in colorful colors and creates different shapes for it (pyramids, balls, etc.). This helps to make it commercially attractive compared to a real hydrogel for plants. It is impossible to fully grow plants on such an aquagrunt. It usually decorates the interior (Figure 1).

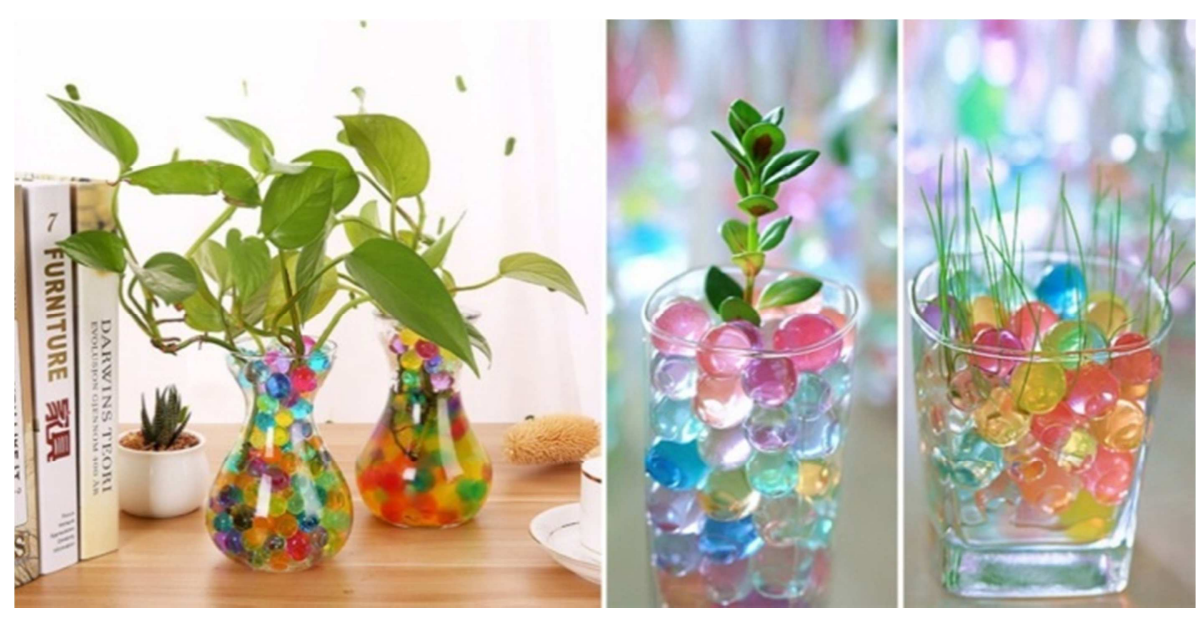

Figure 1. Application of decorative aquagrunt.

Neither hydrogel nor aquagrunt are substitutes for soil.

Advantages of hydrogel for plants:

1. high moisture-retaining properties;

2. ability to maintain humidity for a long time

3. acceleration of plant growth;

4. prevention of stagnation of moisture, rotting of roots;

5. aesthetic appearance;

6. ease of use. [14]

Disadvantages of hydrogel balls:

1. it can not be used for growing seeds with a leathery shell and plants with massive roots;

2. the appearance of mold on the balls with prolonged exposure to sunlight;

3. impossibility of repeated application;

4. lack of nutrients. [15]

Next, we will consider the drawings of cuttings planted on a normal substrate (Figure 2) and cuttings planted on a conventional substrate with gel (Figure 3).

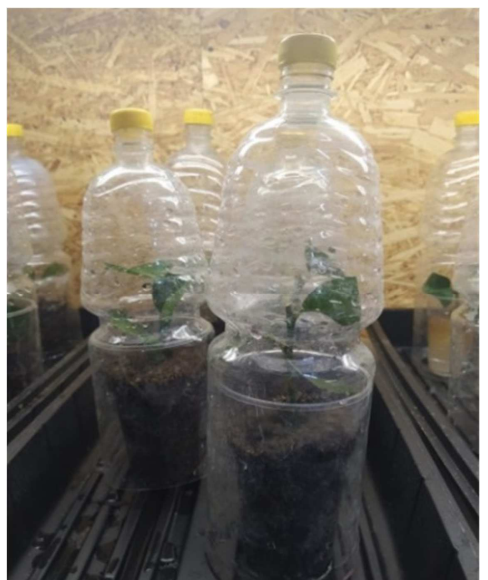

Figure 2. Cuttings planted on a normal substrate.

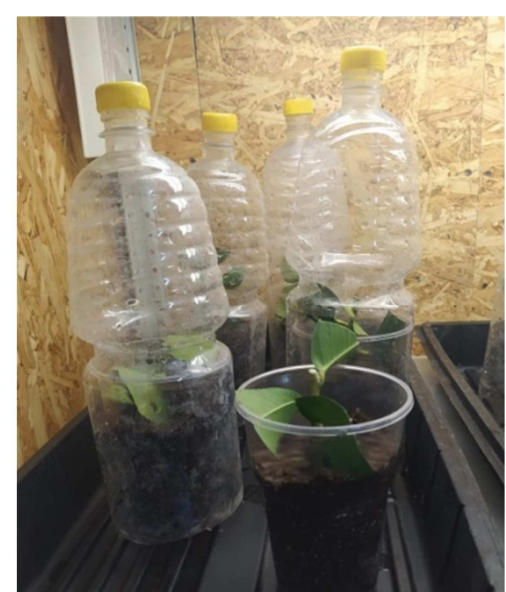

Figure 3. Cuttings planted on a conventional substrate with gel.

Next, consider the cuttings planted with gel (Figure 4).

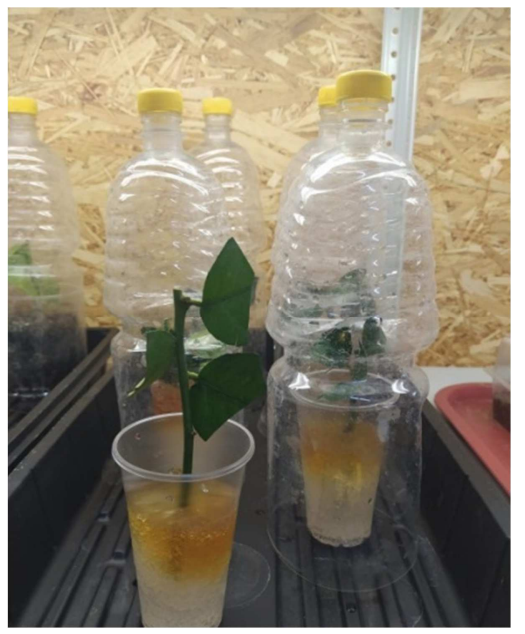

Figure 4. Cuttings planted with gel. 


\section{Results}

Now let's look at more detailed information about planting plants in the form of tables.

Table 1. Control of plant growth on 16.03.2021.

\begin{tabular}{|c|c|c|c|c|c|c|c|}
\hline \multirow[b]{2}{*}{$\begin{array}{l}\text { No. of } \\
\text { experience }\end{array}$} & \multirow[b]{2}{*}{ Experimental plant } & \multirow[b]{2}{*}{ Substrate } & \multirow[b]{2}{*}{$\begin{array}{l}\text { Boarding } \\
\text { date }\end{array}$} & \multicolumn{4}{|c|}{ Control 16.03.21, 21\% } \\
\hline & & & & Non-viable & $\begin{array}{l}\text { No } \\
\text { changes }\end{array}$ & $\begin{array}{l}\text { Dropped } \\
\text { the leaves }\end{array}$ & Shoots \\
\hline 1 & Cuttings (Tashkent variety) & Turf land, sand, peat $(1: 1: 1)$ & 05.03 .2021 & & 40 & 60 & \\
\hline 2 & Cuttings (Tashkent variety) & Turf land, sand, peat $(1: 1: 1)+$ gel & 05.03 .2021 & & 60 & & 40 \\
\hline 3 & Sapling (2 years) & Turf land, sand, peat $(1: 1: 1)+$ gel & 16.03 .2021 & & & & \\
\hline 4 & Sapling (2 years) & Turf land, sand, peat $(1: 1: 1)$ & 16.03 .2021 & & & & \\
\hline 5 & Cuttings (Tashkent variety) & gel & 05.03 .2021 & & 20 & 80 & \\
\hline
\end{tabular}

Table 2. Control of plant growth on 05.04.2021.

\begin{tabular}{|c|c|c|c|c|c|c|c|}
\hline \multirow{2}{*}{$\begin{array}{l}\text { No. of } \\
\text { experience }\end{array}$} & \multirow{2}{*}{ Experimental plant } & \multirow{2}{*}{ Substrate } & \multirow{2}{*}{$\begin{array}{l}\text { Boarding } \\
\text { date }\end{array}$} & \multicolumn{4}{|c|}{ Control 05.04.21, 21\% } \\
\hline & & & & Non-viable & No changes & Dropped the leaves & Shoots \\
\hline 1 & Cuttings (Tashkent variety) & Turf land, sand, peat $(1: 1: 1)$ & 05.03 .2021 & & 60 & 40 & \\
\hline 2 & Cuttings (Tashkent variety) & Turf land, sand, peat $(1: 1: 1)+$ gel & 05.03 .2021 & & & 45 & 55 \\
\hline 3 & Sapling (2 years) & Turf land, sand, peat $(1: 1: 1)+$ gel & 16.03 .2021 & & & 100 & \\
\hline 4 & Sapling ( 2 years) & Turf land, sand, peat $(1: 1: 1)$ & 16.03 .2021 & & 97 & 3 & \\
\hline 5 & Cuttings (Tashkent variety) & gel & 05.03 .2021 & & 60 & 40 & \\
\hline
\end{tabular}

Table 3. Control of plant growth on 12.04.2021.

\begin{tabular}{|c|c|c|c|c|c|c|c|}
\hline \multirow{2}{*}{$\begin{array}{l}\text { No. of } \\
\text { experience }\end{array}$} & \multirow{2}{*}{ Experimental plant } & \multirow{2}{*}{ Substrate } & \multirow{2}{*}{$\begin{array}{l}\text { Boarding } \\
\text { date }\end{array}$} & \multicolumn{4}{|c|}{ Control 05.04.21, 21\% } \\
\hline & & & & Non-viable & No changes & Dropped the leaves & Shoots \\
\hline 1 & Cuttings (Tashkent variety) & Turf land, sand, peat $(1: 1: 1)$ & 05.03 .2021 & & 60 & 40 & \\
\hline 2 & Cuttings (Tashkent variety) & Turf land, sand, peat $(1: 1: 1)+$ gel & 05.03 .2021 & & 20 & 20 & 60 \\
\hline 3 & Sapling (2 years) & Turf land, sand, peat $(1: 1: 1)+$ gel & 16.03 .2021 & & & & 100 \\
\hline 4 & Sapling (2 years) & Turf land, sand, peat $(1: 1: 1)$ & 16.03 .2021 & & & & \\
\hline 5 & Cuttings (Tashkent variety) & gel & 05.03 .2021 & & 60 & 40 & \\
\hline
\end{tabular}

\section{Methods and Discussion}

The problem with growing plants at home is that the earth is most often infected with pathogenic organisms. In my opinion, and based on my article, the hydrogel will allow you to grow healthy seedlings.

When growing domestic plants, hydrogel should not be used for all plants. It is only necessary to use it for plants that consume a large amount of water and require frequent watering. Hydrogel is not suitable for everyone, more often it is plants with dense leaves that do not require watering for months. This means that the earth in the pot will be wet for a long time, and fungi and algae will begin to grow on the soil surface, thereby blocking air access to the roots of plants. In the photos you can clearly see that in my experiment the plant takes root well and grows both in a hydrogel mixed with the ground and in ordinary soil.

Thus, in this method, I was able to find out the amazing properties of the hydrogel.

\section{Conclusion}

Thus, when performing this experiment, the air temperature was maintained in the rooting department at $22-28^{\circ} \mathrm{C}$, the humidity was about 40 . The light mode was observed: 14 hours (from 08: 00 to 22: 00). Watering and spraying of experimental plants was not carried out.

The planted plants were placed in microparticles.

It was found that the percentage of viable plants in the substrate with the addition of gel is higher than in the substrate without the addition of gel. In the substrate with the addition of gel, shoots on cuttings (1.5-5.0 cm long) are observed after 11 days. There are no shoots in the substrate without the addition of gel, after 30 days there are no changes on the plants. Also, in the substrate with the addition of gel, the quality of cuttings and seedlings is higher. For the purity of the experiment, it is recommended to test in the open ground for a longer period of time.

We wish our scientists success in their work, we hope that their developments will be successfully implemented in production and will help to increase the yield of agricultural crops.

\section{References}

[1] Yarkaeva A. The effect of hydrogel on plant growth // Start in science. - 2016. - No. 1. - p. 35-40.

[2] Artyushin A. M., Przhevalskaya JI. K., Epishina G. P., etc. Water-absorbing polymers in agriculture. Chemizats. S. X, 1991, No. 5, pp. 22-26.

[3] Ivanov V. B., Plotnikova I. V., Zhivukhina E. A. Practicum on plant physiology: textbook. help. / Ed. V. B. Ivanov. Moscow: Akademiya, 2001. -144 p. 
[4] Meskheteli A. Hydrogel - "eco-soil" / / Nauka i zhizn, No. 5, 2001.

[5] Chesnokov V. A. Bazyrina E. N., Bushueva T. M. and Ilyinskaya N. L. Growing plants without soil. Publishing house of the Leningrad University, 1960-163 p.

[6] Gromov A. N. The book of a flower grower. - M.-1983. - 225 p.

[7] Alexandrova M., Alexandrova P. Indoor floriculture / M.: Labyrinth-Press, 2004 - - 416s. (The "Golden Collection" series).

[8] Retrieved August 16, 2021 from http://www.tv2.tomsk.ru/polezno/uchimsya-vyrashchivat-tsvet y-bez-zemli.

[9] Retrieved August 16, 2021 from http://www.kartoshki.net/articles/gidrogel-gotovyi-grunt-dlyarastenii.
[10] Retrieved August 16, 2021 from http://www.tv2.tomsk.ru/polezno/uchimsya-vyrashchivat-tsvet y-bez-zemli.

[11] Retrieved August 16, 2021 from http://www.gidrogel.ru/puregel_faq.htm.

[12] Retrieved August 16, 2021 from http://www.e1.ru/articles/green_corner/page_3/009/338/article 9338.html.

[13] Retrieved August 16, 2021 from http://www.robo-mir.ru/shop/1647/desc/gidrogel-dlja-cvetovakvagrunt.

[14] Retrieved August 16, 2021 from https://science-start.ru/ru/article/view?id=8.

[15] Retrieved August 16, 2021 from https://nsportal.ru/ap/library/drugoe/2019/10/16/nauchno-issle dovatelskaya-rabota-vliyanie-gidrogelya-na-rost-rasteniya. 